\title{
Will Asian carp take over the Great Lakes?
}

\author{
M. E. Vroman \\ College of Business, Northern Michigan University, Marquette, \\ Michigan USA
}

\begin{abstract}
This paper examines the legal and legislative efforts to prevent the invasive Asian carp species from gaining access to Lake Michigan and thereby populating all the Great Lakes. So far appeals to the US Supreme Court and a case filed in the US District Court in Illinois have unsuccessfully argued for an injunction closing the Chicago Area Waterway System (CAWS) canals that connect the Des Plaines River to Lake Michigan. The Army Corp of Engineers, which has jurisdiction over the CAWS, has installed a system of electric barriers, which it insists is adequate to prevent the carp from accessing Lake Michigan. Unfortunately, these barriers are not entirely effective. In June 2010, a commercial fisherman caught a bighead carp north of the barriers in a lake only six miles from Lake Michigan, and Asian carp eDNA has been identified in Lake Michigan. Court rulings to date make it clear that nothing short of a proven, established, breeding population will be deemed threatening enough to justify a court order closing the CAWS connection to Lake Michigan. Of course if, and when, this is proven, it will be too late to prevent the fish from establishing themselves in the Great Lakes. Once the carp are established, the entire ecosystem of the Great Lakes is likely to change. This could be disastrous for both the fish that currently inhabit the lakes and the people and industries that depend on them. Since legal efforts appear ineffective, what other actions are possible that might prove successful in protecting the Great Lakes from Asian carp? Federal legislation and numerous agencies are seeking solutions but most experts agree that the best way to prevent a bilateral exchange of invasive species between the Great lakes and the Mississippi River Basin is to sever the CAWS connection that joins the two water systems.

Keywords: Asian carp, bighead carp, silver carp, Great Lakes, Chicago Area Waterways (CAWS), Lake Michigan, Mississippi River Basin, eDNA, injunction, electric barriers, court rulings, legislation, hydrologic separation.
\end{abstract}




\section{Introduction}

The Great Lakes of North America form the largest group of freshwater lakes in the world, holding more than twenty percent of the world's surface freshwater and ninety-five percent of North America's (Barlow [1]). There are already at least 185 non-native species in the five lakes that make up the Great Lakes and most do not get media attention (Hausman [2]). One that has gotten a lot of attention lately is the Asian carp. Asian carp were purposefully brought into the United States by southern aquaculture facilities that imported them to control algae in their fish breeding ponds and the US government, which brought them in for research. These fish eat up to 40 percent of their body weight in algae and plankton every day (Guarino [3]). Unfortunately, but not unpredictably, these fish escaped the confines of their aquaculture ponds during the Mississippi River flooding of the late 1980s and early 1990s (Egan [4]). Once freed, the Asian carp population exploded since they are prolific breeders with no natural predators in the Mississippi Basin. Within a few decades, they have become the dominant fish species in the Illinois, Mississippi, and Missouri Rivers (Massing [5]).

There are actually two sub-species of Asian carp that threaten the Great Lakes-bighead carp and silver carp. Bighead carp can grow to over five feet in length and weigh over 100 pounds; the silver carp is somewhat smaller but just as voracious (Walsh [6]). These fish have an established reputation for destroying ecosystems by gorging themselves and starving out other species. They have been described as "eating machines" and the "locusts of rivers," eating so much plankton they eliminate the food that trout, bass, whitefish, and other Great Lakes fish need to survive [7]. Asian carp are not only voracious eaters that threaten indigenous fish; they also threaten boaters by turning themselves into potentially lethal missiles. The sound of boat motors often startles silver carp and causes them to jump out of the water. Reports of 60pound flying carp hitting boaters are not uncommon [8]. The economic consequences an abundance of these fish could have on the Great Lakes fishing and tourist industry could be as much as 7 billion dollars annually [9]. In addition, there are 800,000 jobs which are dependent on these industries (Kolar and Lodge [10]).

Just how destructive an Asian carp invasion would be to the Great Lakes has led to a fierce debate among researchers, environmental groups and governments. Not everyone thinks Asian carp would be able to thrive in the Great Lakes or cause serious problems but as more and more research is conducted it is becoming harder for this position to be maintained [11].

\section{The Chicago Sanitary and Ship Canal}

In 1900, the direction of part of the Chicago River was reversed by the United States Army Corps of Engineers (Corps) when it opened the Sanitary and Ship Canal [12]. The 28-mile long canal was originally built to carry sewage and wastewater away from the city of Chicago. In 1910 and 1922, two more canals were built and added to the system. These three canals are now the only shipping 
link between the Great Lakes and the Mississippi-river system. They connect the south branch of the Chicago River to the Des Plaines River to Lake Michigan, and Lake Michigan provides access to all the Great Lakes. The canals are part of the Chicago Area Waterway System (CAWS) and, by law the Corps is tasked with maintaining navigation through its locks and waterways [11].

When confronted with the threat of an Asian carp invasion, the Corps installed a series of electric barriers in the canals in an effort to prevent the carp from gaining access to Lake Michigan. Unfortunately, these barriers do not appear to be entirely effective (Lam [13]). The Corps' own tests show that at its current strength, the barrier does not repel carp smaller than $5 \frac{1}{2}$ inches. This is because the electric barrier is operating at half its possible voltage due to barge operators' fear that someone could fall off a barge into the electrified water, or a spark from flammable cargo could ignite a fire (Hood [14]).

On June 22, 2010, a commercial fisherman caught a bighead carp north of the Corps' barriers in Lake Calumet, which is only six miles from Lake Michigan [15]. This was the first live Asian carp found north of the electric barrier system and the second in the CAWS. Even more ominous is the fact that Asian carp eDNA has been identified in Lake Michigan [16].

\section{Legal action}

For whatever reasons, Asian carp were allowed to multiply with impunity for decades to the point where they have now taken over the Mississippi River system. Virtually no action was taken to control or eliminate them until it appeared they were ready to invade the Great Lakes. When this became a real possibility Michigan and several other states filed a lawsuit seeking to close off the CAWS canals that would allow the fish easy access to the Great Lakes. The State of Illinois, however, vehemently opposed this and has consistently argued that the threat the Asian carp pose to the Great Lakes ecosystem and recreational industries is not sufficient to warrant closing the only shipping canals that connect the Great Lakes Basin to the Mississippi River Basin [17].

\subsection{United States Supreme Court}

When the Corps refused to voluntarily close the CAWS, Michigan, Minnesota, New York, Ohio, Wisconsin and the Province of Ontario joined together and filed a lawsuit asking the United States Supreme Court to order the immediate closure of the canals. The State of Illinois and the Corps, which were codefendants, filed a counter-suit. The Obama administration's Solicitor General (current Supreme Court Justice Elena Kagan) sided with Illinois and urged the Supreme Court not to hear the case by claiming that the Corps and other federal agencies were already taking adequate action to stop the Asian carp [18]. The Supreme Court agreed and refused to hear the case. This allowed the administrative process to run its course as defendants had requested [18]. 


\subsection{Illinois Federal District Court}

Failing in their efforts to get a hearing with the Supreme Court, the states of Michigan, Wisconsin, Ohio, Minnesota and Pennsylvania filed a new lawsuit against the Corps and the Metropolitan Water Reclamation District of Greater Chicago (District) in the United States District Court for the Northern District of Illinois [19]. This suit challenged the Corp's administrative decisions related to controlling the Asian carp migration [19, pp.3-5]. It also alleged that the continued operation of the CAWS was a public nuisance that threatened the Great Lakes, the natural resources within them, and the public's right to use and enjoy the waters. Specifically, the states sought "preliminary and permanent relief in the form of a mandatory injunction compelling Defendants to take all available measures, consistent with the protection of public health and safety, to prevent the emigration of Asian Carp through the CAWS into Lake Michigan" [19, pp. 37-38].

On December 2, 2010 Judge Robert Dow issued an opinion denying the relief sought. He agreed that closing the CAWS would produce immediate harm to the region's economy and potentially result in flooding and shipping congestion [19, pp. 3-4, p. 106]. The ecological and economic harm the Asian carp would cause the Great Lakes and its tourist and commercial fishing industry was not "imminent" he said. Therefore, he ruled that the plaintiffs were unsuccessful in proving the legal elements necessary for an injunction to issue. In support of his ruling, the judge reviewed the scientific evidence presented at the hearing and stated that although Asian carp eDNA had been found in Calumet Harbor on Lake Michigan, it did not mean there were live carp in the lake [19, pp. 77-80, 87-90, 88-89]. According to the judge, the fact that plaintiffs' experts concluded that it did mean there were live Asian carp in Lake Michigan, and that defendants' experts concluded it did not, was a difference in opinion. This difference of opinion, he said, did not render the Corps' refusal to close the canal an arbitrary and capricious decision, which is what is required for the court to reverse the administrative agency's decision [19, pp. 48-49].

The court's ruling was largely based on its belief that Asian carp do not pose an "imminent threat" to the Great Lakes in a "legal" sense [19, p. 41]. The troubling conclusion that can be drawn from this case is that the amount and quality of scientific evidence necessary to meet the "imminent threat" element of the preliminary injunction test is essentially insurmountable in the context of an invasive species. Although Judge Dow acknowledged that "the potential harm in a worst case scenario is great," [19, p. 109] he went on to say that even if a large population of Asian carp were found in Lake Michigan, "it is far from certain that Asian carp can survive and reproduce in the Great Lakes" [19, p. 95]. Given this ruling, it appears that nothing short of an established, significant, proven breeding population would be sufficient to satisfy the imminent harm requirement necessary for a preliminary injunction to issue - and if this is the case, then obtaining a court order requiring the closure of CAWS after Asian carp have established themselves in the Great Lakes would be pointless. 


\section{Legislation}

Federal legislation has created more than 148 federal programs involving at least ten federal agencies to manage the natural resources in the Great Lakes Basin [20]. Most of these programs focus on water use but a few target invasive species [21]. Recognizing the difficulty this decentralized approach presents when developing a comprehensive strategy for protecting the Great Lakes, President George W. Bush issued an executive order creating the Great Lakes Interagency Task Force (ITF). It was hoped that the ITF would coordinate all programs governing the Great Lakes through the formation of the Great Lakes Regional Collaboration (GLRC) [22]. The GLRC includes the ITF, the Great Lakes Governors' Council, the Great Lakes and St. Lawrence Cities Initiative, American Indian tribes, and a task force of members of Congress from the region [23].

\subsection{Great Lakes Restoration Initiative}

One of the GLRC's most significant accomplishments so far has been the Environmental Protection Agency's Great Lakes Restoration and Initiative whose purpose is to protect and restore the Great Lakes [24]. The Great Lakes Restoration and Initiative has established a task force of eleven federal agencies who are developing an action plan which covers fiscal years 2010-2014. The action plan seeks to address five urgent Great Lakes issues, one of which is how to combat invasive species, particularly the Asian carp [24].

\subsection{The Asian Carp Regional Coordinating Committee}

The Asian Carp Regional Coordinating Committee was established to combat Asian carp and has received \$104 million from federal agencies and the Great Lakes Restoration Initiative. So far, this money has been spent to fund sampling and DNA testing of rivers and the Chicago Sanitary and Ship Canal; electrofishing and netting of Asian carp; scientific research to investigate methods of controlling carp, and plans for a rapid response to poison live carp if they are found in the Great Lakes [25].

The carp committee is composed of the White House Council on Environmental Quality, appointed by John Goss, the nation's Asian carp czar; the Army Corps of Engineers; the U.S. Fish and Wildlife Service; the U.S. Geological Survey; the Environmental Protection Agency; the Great Lakes Fishery Commission; environmental groups, and state departments of natural resources. The most updated version of the Committee's control plan can be read at www.asiancarp.org.

\subsection{The Asian Carp Prevention and Control Act}

The Asian Carp Prevention and Control Act was signed into law by President Obama on December 14, 2010. It lists bighead carp as injurious wildlife under the Lacey Act. This makes it illegal to import or transport live bighead carp, 
including viable eggs or hybrids of the species, across state lines, except by permit for zoological, education, medical, or scientific research purposes [26]. It is hoped that this will prevent commercial fisheries from transporting live carp that might escape into lakes or streams or the use of carp fry as live bait, which could also escape and reproduce.

\subsection{Proposed bills}

Some Congressional members, from states whose economies depend on the Great Lakes, have proposed several bills with the purpose of keeping the carp out of the Great Lakes. In 2010 U.S. Senators Debbie Stabenow and Dick Durbin introduced legislation in the Senate that contained specific proposals designed to keep Asian carp and other invasive species from entering the Great Lakes. The Permanent Prevention of Asian Carp Act would have required the Corp to conduct and expedite a study describing engineering options for permanently separating the Mississippi River Basin from Lake Michigan. It would also have required a detailed analysis of the environmental benefits and costs of each option. This legislation did not pass but was proposed again in 2011 as the Stop Asian carp bill. This bill is essentially the same as the 2010 proposal and also includes requirements that the Great Lakes basin, and all waters that connect to it, be monitored for Asian carp [27].

\section{Hydrologic separation}

Since the three-part electrical barrier installed by the Corp does not appear to be keeping all the Asian carp out of the CAWS, most discussions and legislative proposals deal with the prospect of hydrologically separating Lake Michigan from the Mississippi River basin [28]. According to at least one expert, and contrary to what most people believe, it is possible to separate these two water systems without closing the CAWS' busiest shipping routes: the O'Brien and Chicago locks. Methods to separate the basins at points other than the locks are being studied and, if possible, should eliminate the objections of industries that depend on keeping them open (Brammeier et al. [29]). However, the sad truth is that while this is an essential and important measure it is not the sole solution to the problem. In the summer of 2010 Asian carp were discovered in the Wabash River in Indiana. The Wabash has a tributary that seeps into marshlands near the Maumee River. If flooding allows Asian carp to cross these marshlands and enter the Maumee River, they have a straight path to Lake Erie [30]. Lake Erie, with its shallow waters and plankton-rich environment, would be the most hospitable of all the Great Lakes for the proliferation of the Asian invaders [30]. This means additional action must be taken to prevent the carp from accessing the Great Lakes from the east.

The biggest objections to hydrologic separation are based on the detrimental impact it would have on the shipping industry on which much of the Midwest economy depends. Such a project would also require extensive new infrastructure in the Chicago area. These infrastructure upgrades would be 
extremely costly but they would also benefit the entire Great Lakes and Mississippi region by improving water quality, tourism, and recreation while simultaneously creating numerous local and regional jobs. The one-time capital cost to separate the two basins would be very high and some argue that this cost is not justified because the ecological and economic damage the carp would allegedly cause is not certain. However, a recent study by four reputable scientists disagrees. The study's authors conclude that:

Hydrologic separation is the only option which closes the aquatic connection between the two basins and does not require continuous operation and maintenance of various technologies that have some risk of failure (Rasmussen et al. [32]).

It should also be noted that although most of the discussion about closing the CAWS connection is aimed at preventing the Asian carp from migrating from the Mississippi River basin to the Great Lakes, separation would also prevent the migration of invasive species from entering the river system from the Great Lakes. One fish scientists want to keep from entering the Mississippi River basin is the Eurasian ruffe. The ruffe is also a prolific breeder that competes with native game fish such as yellow perch for food and if it migrates from the Great Lakes to the river system it could seriously harm its fisheries and ecosystem (Lam [33]).

As stated above, the CAWS canals that connect Lake Michigan to the Chicago River are not the only way carp can enter the Great Lakes. Although it may be the easiest, there are at least 13 other pathways for the fish to get into the Great Lakes. Right now, spawning carp in Indiana's Wabash River are actually closer to Lake Erie than spawning carp near Chicago are to Lake Michigan. Although not all scientists agree, a researcher with the U.S. Geological Survey in Missouri, thinks Asian carp could probably survive in all the Great Lakes because they feed in the top layers of water, where the temperatures are warmer (Jones [34]).

Currently, the Army Corps of Engineers is conducting a \$25-million study on the feasibility of separating the two water basins but this study will not be finished until 2015 when many believe it will be too late to take remedial action [33].

\section{Commercial fishing}

Harvesting Asian carp is advocated by some as the surest way of reducing the unwanted carp population in the U.S. Some businesses already sell the fish in overseas markets while others are trying to find domestic uses for Asian carp such as making them into fish sticks, fertilizer or injecting their protein into tortillas.

However, scientists and policy makers are opposed to creating a new industry for fishing, marketing and eating Asian carp. Kevin Irons, aquatic nuisance species program manager for the Illinois Department of Natural Resources, 
thinks the idea of creating a multimillion-dollar fishery for Asian carp is dangerous. He fears that businesses which invest heavily in processing plants and jobs in those plants will not want to completely eradicate the Asian carp on which their investment depends.

Yet there are scientists who believe "harvest is the best chance we have" to lower fish numbers in the short term. The fishermen themselves claim they could catch $90 \%$ of Asian carp in five years if they could sell them (Lam [35]).

\subsection{Foreign markets}

The Chinese are particularly fond of Asian carp, especially bighead carp, and have greatly depleted their indigenous supply. There are many commercial fishing companies who say they are eager to capture unwanted Asian carp in American waters and sell them to consumers in China. However, one serious impediment to this plan is that the Chinese prefer their Asian carp fresh. Even if the Chinese can be convinced to eat carp that have been frozen, commercial fisheries claim they need government subsidies to make their plans work and, so far, the government has not been willing to subsidize an industry built around an invasive species (Thompson [36]).

\subsection{Domestic markets}

Asian carp are low in fat, high in healthy oils and free of many of the contaminants that plague other species. This is because they eat only plankton. As such, some advocate re-naming the fish "silverfin" and convincing Americans it is a local, wild-caught fish that is both tasty and good for them. This is a strategy patterned after the commercial success of renaming other fish such as Patagonian toothfish, which was renamed Chilean seabass and slimehead, which is now sold as orange roughy. Both of these re-naming and marketing campaigns have made the fish so popular they have become overfished (Lam [35]). The hope is that re-naming Asian carp "silverfin" and successfully marketing them could result in their being overfished to the point of eradication.

\section{Conclusion}

The Great Lakes provides life and livelihood to more than 40 million people. According to the Brookings Institute, if it stood alone as a country, the Great Lakes economy, with a gross regional product of $\$ 4.2$ trillion, would be the second largest in the world, next only to that of the United States (Barlow [36]). The damage Asian carp could do to this economy and ecosystem is immense. Already Bighead carp have been collected from waters in 26 states and silver carp from 16 states. They are now in a third of the central U.S., in rivers from Louisiana to Minnesota, and they keep driving north (Jones [34]). The fact that nothing was done about these fish for the thirty or so years it took them to take over the Mississippi River basin is unexplainable. The possibility that these fish will be allowed to take over the Great Lakes is unthinkable. Most experts agree 
that the only permanent solution to the threat of Asian carp has to include separating the waters of the Great Lakes from the Mississippi River basin. It is now past the point of studying whether to separate the Great Lakes from the Mississippi River system and instead resources should be directed toward how to separate them. Although separation of the water basins is essential, other measures to control Asian carp such as eradication procedures in identified "hotspots", instituting flood controls and implementing spawning controls and fish bounty programs also need to be pursued.

Since legal efforts to mandate solutions to the Asian carp's problem have failed, the future is dependent on legislative action requiring (and funding) the separation of the Great Lakes and Mississippi waterways as well as other eradication measures. It is not the difficulty of engineering a system that separates the two water systems, while preserving shipping between the two, which is the biggest obstacle to preventing Asian carp from entering the Great Lakes. The real challenge is finding the political will and money necessary to make it happen.

\section{References}

[1] Barlow, M., Our Great Lakes Commons: A People's Plan to Protect the Great Lakes Forever. p. 9, http://www.blueplanetproject.net/resources/ reports/GreatLakes-0311.pdf

[2] Hausman, J., Asian carp issues aired in Muskegon 'town hall meeting', MLive: http://www.mlive.com/news/muskegon/index.ssf/2011/05/asian carp.html

[3] Guarino, M., Asian Carp: How One Fish Could Ruin the Great Lakes, The Christian Science Monitor, http://www.csmonitor.com/USA/2010/0316/ Asian-carp-how-one-fish-could-ruin-the-Great-Lakes.

[4] Egan, D., DNA Water Test for Asian Carp Endorsed, JSOnline, http://www.jsonline.com/news/wisconsin/112984379.html.

[5] Massing, D., Erie-area fishermen, conservationists see Asian carp director as positive step toward stopping invader, www.goerie.com/ apps/pbcs.dll/article?AID=/20100917/NEWS02/309169841/-1/etn.

[6] Walsh, B., Asian Carp in the Great Lakes? This Means War!, Time, www.time.com/time/health/article/0,8599,1962108,00.html.

[7] Absolute Michigan, Michigan Invasive Species: Asian Carp, www.absolutemichigan.com/dig/michigan/michigan-invasive-species-asian -carp.

[8] Asian carp control, http://asiancarp.org/background.asp

[9] New Bill to Battle Asian carp, http://latourette.house.gov/news/pressreleases/new-bill-to-battle-asian-carp.aspx , July 18, 2011

[10] Kolar, C.S. \& Lodge, D.M., Ecological Predictions and Risk Assessment for Alien Fishes in North America, Science, vol. 298 (November 8, 2002), pp. 1233-1236., See also U.S. and Canadian Scientists Warn Great Lakes Asian Carp Threat is Real; Urge Separating Great Lakes, Mississippi River, http://freshwaterfuture.org/news-announcements.html/38/ (July 1, 2011) 
[11] United States Army Corps of Engineers, Chicago District, Dispersal Barrier Efficacy Study, p. 14 www.lrc.usace.army.mil/pao/02June2010_InterimIII .pdf.

[12] United States Army Corps of Engineers, Chicago District, Dispersal Barrier Efficacy Study, p. 14 www.lrc.usace.army.mil/pao/02June2010_InterimIII .pdf., citing 33 CFR $\S 207.420$ (a) to (b).

[13] Lam, T., Asian carp: Battle lines are drawn at the Chicago ship canal, Detroit Free Press, http://www.freep.com/article/20110719/NEWS05/ 107190387/Asian-carp-Battle-lines-drawn-Chicago-ship-canal (July 19, 2011))

[14] Hood, J., Carp Creeps into Lake Calumet, Chicago Tribune, http://articles.chicagotribune.com/2010-06-23/news/ct-met-0624-asian-carp -found-20100623_1_electric-barriers-lake-michigan-carp

[15] Army Corps, $201 \overline{0}$ WL 5018559 at 7, n 10.

[16] MRRWG eDNA Asian carp surveillance, http://www.lrc.usace.army.mil/ asiancarp/eDNAresultsmap.pdf

[17] Memorandum for the United States in Opposition to the Motion for Preliminary Injunction Submitted by the State of Michigan at 20-21, Wisconsin v Illinois, _ US _ ; 130 S Ct 2397; 176 L Ed 2d 765 (2009) (No. 1, Original), available at 2010 WL 1389746.

[18] Wisconsin v Illinois, __ US _ ; 130 S Ct 2397; 176 L Ed 2d 765 (2009).

[19] Michigan v U.S. Army Corps, 2010 U.S. Dist. LEXIS 127376; 41 ELR 40041 (N.D. Ill., Dec. 31, 2011); Motion granted by, in part, Motion denied by, in part, Stay granted by, in part, Stay denied by, in part Michigan v. United States Army Corps, 2011 U.S. Dist. LEXIS 35282 (N.D. Ill., Mar. $31,2011)$

[20] U.S. Gen. Accounting Office, Great Lakes, An Overall Strategy and Indicators for Measuring Progress Are Needed to Better Achieve Restoration Goals 4 (2003); U.S. EPA, Great Lakes Federal Programs, http://hsgac.senate.gov/071603glgaoreport.pdf

[21] Great Lakes Basin Compact, Pub. L. No. 90-419, 82 Stat. 414, 415-17 (1968).

[22] Exec. Order No. 13,340, 69 Fed. Reg. 29,043 (May 20, 2004).

[23] Great Lakes and St. Lawrence Cities Initiative, http://www.glslcities.org/

[24] H.R. 2996, 111th Cong., at 66 (as passed by House, June 26, 2009). and Veale, S., Schumer Promotes Great Lakes Initiative, Democrat \& Chronicle (Rochester, N.Y.), Aug. 25, 2009, at http://www.democratan dchronicle.com/article/20090825/NEWS01/908250329/1002/NEWS/Schu mer-promotes-Great-Lakes-initiative

[25] Asian carp control, http://asiancarp.org/about-the-committee/

[26] President Signs Levin's Asian Carp Prevention and Control Act into Law, http://levin.senate.gov/newsroom/press/release/?id=14bf4e07-8476-4f36-ba 03-91a9e7c52f27, December 14, 2010

[27] http://www.govtrack.us/congress/billtext.xpd?bill=s112-471\&version=is\& $\mathrm{nid}=\mathrm{t} 0 \% 3 \mathrm{Ais} \% 3 \mathrm{~A} 39$ 
[28] Testimony of Andy Buchsbaum, Director of the Great Lakes Regional Center, National Wildlife Federation, before the subcommittee on water and power, Senate Natural Resources Committee, February 25, 2010, http://www.healthylakes.org/wp-content/uploads/2011/04/02-252010TESTIMONY-Buchsbaum-AsianCarpSenateHearing.pdf

[29] Brammeier, J.B., Scudder, M., \& Irwin, P., Preliminary feasibility of ecological separation of the Mississippi River from the Great Lakes to prevent the transfer of invasive aquatic species (2008) http://www.greatlakes.org/Document.Doc?.id=473

[30] Asian Carp Regional Coordinating Committee, Preventing Establishment of Asian Carp in the Great Lakes: The Wabash/Maumee River Connection, www.asiancarp.org/documents/MaumeeWabashFactSheet-final.pdf.

[31] National Wildlife Federation, What we do to stop Asian carp. http://www.nwf.org/Wildlife/What-We-Do/Invasive-Species/AsianCarp.aspx

[32] Rasmussen, J. L., Regier, H. A., Sparks, R. E., \& Taylor, W.W., Dividing the waters: The case for hydrologic separation of the North American Great Lakes and Mississippi River Basins, Journal of Great Lakes Research, 2011; doi:10.1016/j.jglr.2011.05.015, http://csis.msu.edu/sites/ csis.msu.edu/files/Carp_Taylor.pdf

[33] Lam, T, Asian carp: Battle lines are drawn at the Chicago ship canal, Detroit Free Press, http://www.freep.com/article/20110719/NEWS05/ 107190387/Asian-carp-Battle-lines-drawn-Chicago-ship-canal (July 19, 2011)

[34] Jones, C., The Jones Report, The truth about Asian carp. http://crisisjones.wordpress.com/2011/07/26/cjr-special-report-asiancarp-primer-research-by-lassiter/ July 17, 2011

[35] Lam, T., Carp can be harvested - but who will eat it?, Detroit Free Press，http://www.freep.com/article/20110721/NEWS06/107210511/Carpcan-harvested-who-will-eat (July 22, 2011))

[36] Thompson, C., China craves carp - If it's fresh, The Detroit News, http://www.freep.com/apps/pbcs.dll/article?AID=2011107210513 (July 21, 2011)

[37] Barlow, M., Our Great Lakes Commons: A People's Plan to Protect the Great Lakes Forever, p.20, http://www.blueplanetproject.net/resources/ reports/GreatLakes-0311.pdf 